\title{
THE PROTECTIVE EFFECT AND THE UNDERLYING MECHANISM OF EPHEDRA SINICA STAPF ON RENAL INJURY IN A MURINE MODEL
}

\author{
XUE WANG $^{1,2 \#}$, WEI FU ${ }^{3 \#}$, HAIYANG LIU $^{1}$, ZHIBIN WANG ${ }^{2}$, HAIXUE KUANG ${ }^{2}$, QIUHONG \\ $\mathrm{WANG}^{4 *}$ \\ ${ }^{1}$ Jiamusi College, Heilongjiang University of Traditional Chinese Medicine, Jiamusi, 154002, China \\ ${ }^{2}$ College of Pharmacy, Heilongjiang University of Chinese Medicine, Harbin, 150040, China \\ ${ }^{3}$ Cavity Mirror Chamber, Jiamusi Cancer Hospital, Jiamusi, 154002, China \\ ${ }^{4}$ College of Traditional Chinese Medicine, Guangdong Pharmaceutical University, Guangzhou, 511470, China
}

*corresponding author: wangqiuh_gdyao@163.com

${ }^{\#}$ Authors with equal contribution.

Manuscript received: November 2019

\begin{abstract}
This study aimed to investigate the protective effect and the underlying mechanism of Ephedra sinica Stapf on renal injury in a murine model. Sixty rats were randomly divided into 5 groups with 12 animals per group as follows: control group, model group, high dose group of Ephedra (20 g/kg bw/day), middle dose group of Ephedra (10 g/kg bw/day), and low dose group of Ephedra (5 g/kg bw/day). Renal injury was induced in rats using a renal ischemia-reperfusion model. Blood urea nitrogen (BUN), serum creatinine (SCr) and malondialdehyde (MDA) in the model group increase significantly while superoxide dismutase (SOD), nitric oxide (NO), and endothelial nitric oxide synthase (eNOS) decrease significantly compared with the control group ( $\mathrm{p}<0.05$ ). In Ephedra groups BUN, SCr, and MDA decrease and SOD, NO, and eNOS increase compared to the model group in a dose-dependent manner. The histo-pathological evaluation showed in the model group appears a renal tubular protein cast with inflammatory cell infiltration, renal interstitial congestion, and visible turbid swelling of renal tubular epithelial cells. The histo-pathological changes are significantly reducing or even disappearing after the treatment with Ephedra. The model group showed severe tissue damage and a large number of apoptotic cells, up-regulation of Bax protein and down-regulation of $\mathrm{Bcl}-2$ protein expression compared to control group ( $\mathrm{p}<0.05)$. Tissue damage in the Ephedra treatment groups is minor, and only scattered apoptotic cells were seen. Bax protein expression in the Ephedra groups was significantly down-regulated and $\mathrm{Bcl}-2$ protein expression was significantly up-regulated in a dose-dependent manner compared to the model group ( $\mathrm{p}$ 0.05). Ephedra can reduce renal injury and improve renal function by reducing oxidative damage, free radical generation, and inhibiting apoptosis.
\end{abstract}

\section{Rezumat}

Acest studiu a urmărit investigarea efectului protector și mecanismul de bază al Ephedra sinica Stapf asupra leziunilor renale la șobolani. Șaizeci de șobolani au fost împărțiți aleatoriu în 5 loturi a 12 animale: lotul control, lotul de animale bolnave, lotul tratat cu doză mare de Ephedra $(20 \mathrm{~g} / \mathrm{kgc} / \mathrm{zi})$, lotul tratat cu doză medie de Ephedra $(10 \mathrm{~g} / \mathrm{kgc} / \mathrm{zi})$ și lotul tratat cu doză mică de Ephedra $(5 \mathrm{~g} / \mathrm{kgc} / \mathrm{zi})$. Leziunea renală a fost indusă la șobolani folosind un model de ischemie-reperfuzie renală. Ureea din sânge (BUN), creatinina serică (SCr) și malondialdehida (MDA) din lotul de animale bolnave cresc semnificativ, în timp ce superoxid-dismutaza (SOD), oxidul nitric (NO) şi nitric oxid sintetaza endotelială (eNOS) scad semnificativ în comparație cu lotul control (p < 0,05). În loturile tratate cu Ephedra, BUN, SCr și MDA scad și SOD, NO și eNOS cresc comparativ cu lotul de animale bolnave, doză dependent. Evaluarea histo-patologică a arătat că în lotul de animale bolnave apare o proteină care produce inflamație, congestie interstițială renală și gonflare vizibilă a celulelor renale epiteliale tubulare. Modificările histo-patologice se reduc semnificativ sau chiar dispar după tratamentul cu Ephedra. Lotul de animale bolnave a prezentat leziuni tisulare severe și un număr mare de celule apoptotice, up-reglarea proteinei Bax și down-reglarea expresiei proteice Bcl-2 în comparație cu lotul control $(\mathrm{p}<0,05)$. Deteriorarea țesuturilor în loturile tratate cu Ephedra este mică și s-au observat doar celule apoptotice împrăștiate. Expresia proteinei Bax din grupurile Ephedra a fost semnificativ down-reglată, iar expresia proteinei Bcl-2 a fost semnificativ up-reglată, doză dependent, comparativ cu lotul de animale bolnave $(\mathrm{p}<0,05)$. Ephedra poate reduce leziunile renale și poate îmbunătăți funcția renală.

Keywords: Ephedra, renal injury, ischemia-reperfusion, oxygen free radical, apoptotic protein

\section{Introduction}

Ischemia-reperfusion injury (IRI) refers to ischemia caused by various causes that determine tissue or organ damage caused by blood perfusion recovery $[1,2]$.
The kidney is one of the organs affected by ischemiareperfusion injury in the clinic [3]. Renal ischemiareperfusion injury (RIRI) is clinically common in acute kidney injury (AKI) and after kidney transplantation 
$[4,5]$. It is one of the main factors that affect the prognosis in the treatment of AKI and the early functional recovery and long-term survival of grafts after renal transplantation [6]. Oxidative stress (OS) is the main pathological factor and mechanism of RIRI [7, 8]. The increased number of free radicals that appear during IRI, induce inflammatory response and apoptosis, and affect kidney function [9, 10]. Ephedra is a dry herbaceous stem of Ephedra sinica Stapf with acrid and slightly bitter taste. It has the effects of inducing sweat, freeing lung, relieving asthma and inducing diuresis to alleviate oedema, being used in the traditional medicine for cold, chest tightness, cough, oedema and bronchial asthma [11, 12]. Ephedra also has the effect of scavenging oxygen free radicals [13]. Studies that investigated the antioxidant and scavenging properties against oxygen free radicals of Ephedra polysaccharide used hot water extraction method in order to obtain a pure Ephedra polysaccharide sample [14, 15]. They showed that Ephedra polysaccharides could scavenge oxygen free radicals and had antioxidant effects. Its use in renal ischemia-reperfusion injury has not been previously reported. Therefore, this study aimed to evaluate the protective effect and the underlying mechanism of Ephedra in renal ischemia-reperfusion injury on a murine model.

\section{Materials and Methods}

\section{Animals}

Male CD-SD rats with the body weight of $240 \sim 260 \mathrm{~g}$ were obtained from the animal house of Heilongjiang University of Traditional Chinese Medicine. The rats were acclimatized to the new laboratory conditions for one week before the experiment and routinely raised. They were fasted, but not banned from the water overnight before surgery. The temperature of the animal room was controlled at $25 \pm 2^{\circ} \mathrm{C}$, the relative humidity was controlled at $50 \% \sim 60 \%$ and the circadian rhythm was mimic by 12 hours light/dark cycle. The ethics committee of Heilongjiang University of Traditional Chinese Medicine approved the animal protocol and the experiment also followed the regulations of the State Science and Technology Commission on the management of laboratory animals.

Ephedra extract solutions preparation

The Ephedra pieces (Chinese Herbal Pieces Factory of Guangdong Medicine Company, China) were soaked in water for 30 minutes, followed by decoction for 50 minutes (defoaming during decoction). The residues were removed from the decoct by filtration in gauze, and then the solution was concentrated with a rotary evaporator (Heidolph Laborota 4000, Merck KGaA, Germany) to the final concentration of $1.0 \mathrm{~g}$ raw Ephedra/mL. Then, the stock solution was diluted with distilled water to obtain the treatment solutions of $0.5 \mathrm{~g} / \mathrm{mL}$ and $0.25 \mathrm{~g} / \mathrm{mL}$. The treatment was administered to the animals by oral gavage in the volume of $0.2 \mathrm{~mL} / 10 \mathrm{~g}$. The groups that receive 1.0 , $0.5,0.25 \mathrm{~g} / \mathrm{mL}$ of Ephedra water decoction were equivalent to the doses of 20,10, $5 \mathrm{~g}$ Ephedra $/ \mathrm{kg}$. Murine model of renal ischemia-reperfusion injury and animal groups

Sixty rats were randomly divided into 5 groups: control group, model group, high dose group of Ephedra (20 $\mathrm{g} / \mathrm{kg})$, middle dose group of Ephedra $(10 \mathrm{~g} / \mathrm{kg})$, and low dose group of Ephedra $(5 \mathrm{~g} / \mathrm{kg}), 12$ rats per group. The rat model of renal ischemia-reperfusion injury: The rats from the model group and Ephedra groups were inhalator anaesthetized with sevoflurane (Chongqing Shenghuaxi Pharmaceutical Co., Ltd., China) and fixed on the operation table. The abdominal skin was cut with surgical scissors, and the abdominal cavity was opened. The right renal hilus was separated and after ligating with a surgical line, the right kidney and renal capsule were separated, and the right kidney was removed. After the left renal hilus were separated, the arteries and veins of the renal hilus were ligated lively with a surgical line to block the renal arteries and veins. After blocking for 45 minutes, the slipknot was released for the kidney blood reperfusion. When the blood reperfusion started the kidney colour changed from dark to red for successful of the model. The abdominal wall and skin were sutured, and the surgical wound was disinfected with iodine solution (Dezhou Tongde Disinfection Products Technology Co., Ltd., China). The penicillin (100,000 IU/kg) (Suzhou Erye Pharmaceutical Co., Ltd., China) was injected intraperitoneally to prevent infection. After the modelling was completed, each rat was sent to the cage for observation and feeding.

The control group was a sham operation group in which the kidney was not removed and the renal arteries and veins were not ligatured. The rest of the procedures were the same as in the model group of rats.

The control group and the model group received orally $2 \mathrm{~mL} / 100 \mathrm{~g}$ physiological saline solution per day for two weeks while the Ephedra groups received Ephedra decoct solution in specified concentrations for 2 consecutive weeks.

During the 2 weeks of the experiment the hair, diet, urination volume, mental activity status, and death of the rats were observed. After 2 weeks of treatment the rats were sacrificed by exsanguination after anesthetized with $10 \%$ chloral hydrate (Guangzhou Peiyu Biological Products Co., Ltd., China). The blood was collected from the abdominal aorta for biochemical determination. Rat kidneys were collected, and the left kidney was placed in 10\% neutral formalin solution (Nanjing Haeckel Biotechnology Co., Ltd., China) for haematoxylin and eosin (HE) staining. The right kidney was deep freeze at $-80^{\circ} \mathrm{C}$ for biochemical index detection.

Biochemical indexed determination

$2 \mathrm{~mL}$ of blood collected from abdominal aorta was centrifuged at $1170 \mathrm{~g}$ for 15 minutes to determine the blood urea nitrogen (BUN) and serum creatinine (SCr) 
FARMACIA, 2020, Vol. 68, 3

(BUN and SCr test kits, Renoir Technology Industry Co., Ltd., Shenzhen, China) by the picric acid method and diacetyl method according to the kit instructions. $1 \mathrm{~g}$ of the renal cortex was homogenated for the determination of superoxide dismutase (SOD), nitric oxide (NO), malondialdehyde (MDA) and endothelial nitric oxide synthase (eNOS). SOD was measured by the xanthine oxidase method (xanthine solution, Beijing Zhongsheng Ruitai Technology Co., Ltd., China). MDA was measured by the thiobarbital method (sorbic acid, Hunan Huari Pharmaceutical Co., Ltd., China; thiobarbituric acid, Shanghai Xinyu Biotechnology Co., Ltd., China), and NO was measured by the nitrate reductase method (NO test kit, Wuhan Chundu Biotechnology Co., Ltd., China) according to the instructions of the kits. The content of endothelial nitric oxide synthase (eNOS) in renal tissue was tested by enzyme-linked immunoassay (ELISA) (ELISA kit, Shanghai Sifeng Biotechnology Co., Ltd., China).

HE staining

The kidney tissue was fixed in a $10 \%$ neutral formalin solution. The fixed tissue block was dehydrated in ascending series of ethanol (Guangzhou Dongye Chemical Industry, China), cleared in xylene (Jinan Aohui Chemical Co., Ltd., China) and embedded in paraffin. The embedded tissue block was cut in pieces of $3 \mu \mathrm{m}$. The tissue was stained with haematoxylin and eosin (Shanghai Tianhe Biotechnology Co., Ltd., China), cleared in xylene, sealed with resin (Shanghai Tianhe Biotechnology Co., Ltd., China). Then, the morphological changes of the tissue were observed under a light microscope (Weifang Mingyang Experimental Analytical Instrument Co., Ltd., China).

The kidney cells apoptosis determination by TUNEL method

TUNEL kit was purchased from Roche, USA. $3 \mu \mathrm{m}$ paraffin sections of kidney tissue were deparaffinised and incubated with proteinase $\mathrm{K}$, a mixed solution of nucleotide and terminal deoxynucleotidyl transferase, horseradish peroxidase-labelled secondary antibody. Then the slides were stained with diaminobenzidine (DAB). Tissue sections were magnified 400 times with a colour image recording input device and a fullautomatic image analyser (Sony Corporation, Japan). 5 visual fields from each section were randomly taken for positive cells (tan or brownish-yellow particles) and total cell count. Then, the apoptotic index (AI) was calculated as follows: $\mathrm{AI}=$ number of apoptotic cells/the total number of cells $\times 100 \%$.

Expression of Bcl-2 and Bax in kidney tissues measured by immunohistochemistry

Bcl-2 and Bax were determined in kidney paraffin sections by immunohistochemistry. Normal goat serum working solution sealed the antigen. Rabbit anti-rat Bax polyclonal antibody and rabbit anti-rat Bcl-2 polyclonal antibody (Beijing Zhongshan Jinqiao Biotechnology Co., Ltd., China) were respectively used as primary antibodies. The paraffin sections were incubated at $37^{\circ} \mathrm{C}$ for 1 hour with the primary antibodies. Normal goat serum was used to seal the antigen. Then the samples were incubated with the secondary antibodybiotin-labelled goat anti-rabbit IgG (Beijing Zhongshan Jinqiao Biotechnology Co., Ltd., China), followed by incubation with horseradish peroxidase-labelled streptavidin solution at $37^{\circ} \mathrm{C}$ for $30 \mathrm{~min}$ and finally stained with DAB Brownish-yellow staining was considered positive.

\section{Expression of Bcl-2 and Bax by Western blot}

Each group of tissue protein was extracted, and the total protein concentration was measured. After SDSPAGE (dodecyl sulphate, sodium salt (SDS)-Polyacrylamide gel electrophoresis), the protein was transferred to a $0.2 \mu \mathrm{m}$ PVDF (polyvinylidene fluoride) membrane. $5 \%$ skimmed milk powder was sealed at room temperature for $2 \mathrm{~h}$, adding rabbit anti-rat Bcl-2 and Bax primary antibody (Beijing Zhongshan Jinqiao Biotechnology Co., Ltd., China). B-actin was used as internal control and the samples were incubated at $4^{\circ} \mathrm{C}$ overnight with rabbit anti-rat $\beta$-actin antibody (Beijing Zhongshan Jinqiao Biotechnology Co., Ltd., China). Then the membrane were washed with TBST (Tris buffered saline + Tween) (Beijing Zhongshan Jinqiao Biotechnology Co., Ltd., China) for 10 minutes, 3 successive times. HRP (Horseradish Peroxidase) goat anti-rabbit secondary antibody (Beijing Zhongshan Jinqiao Biotechnology Co., Ltd., China) was added and incubated at room temperature for $2 \mathrm{~h}$ followed by membrane wash with TBST for $10 \mathrm{~min}$ for 3 successive times. Then the samples were coloured with ECL (Electro-ChemiLuminescence) solution (Beyotime Biological Technology Co., Ltd.) and then analysed using a Gel Doc 2000 gel imager (Bio-Rad, USA) and the bands were analysed with Image J software (National Institutes of Health, USA). The ratio of the grey value of the target gene band to the grey value of the internal reference $\beta$ actin band was used to reflect the expression level of the target gene.

Statistical analysis

SPSS 19.0 (IBM, USA) software was used for the single-factor analysis of variance. The data were expressed as mean \pm standard deviation $(\bar{x} \pm s)$, and the statistical significance was considered if $\mathrm{p}<0.05$ [16].

\section{Results and Discussion}

\section{General observations}

Compared with the control group, the rats in the model group show mental debility, reduced activity, and often bury their heads and curl up. The above phenomenon also appears in each administration group, but it improves significantly compared with the model group, and gradually disappears with the increase of the dosage. Biochemical parameters

In the model group, it is observed a significant increase of BUN, SCr and MDA levels and a significant decrease of SOD, NO, and eNOS compared to the control group 
( $\mathrm{p}<0.05)$. In Ephedra treatment groups, the treatment determine a significant decrease of BUN, SCr, and MDA and a significant increase of SOD, NO, and
eNOS in a dose-dependent manner compared to the model group $(\mathrm{p}<0.05)$ (Table I).

Table I

Effects of Ephedra on biochemical indexes in rats

\begin{tabular}{lccccc}
\hline \multicolumn{1}{c}{ Group } & Control group & Model group & $\begin{array}{c}\text { Low dose } \\
\text { Ephedra group }\end{array}$ & $\begin{array}{c}\text { Middle dose } \\
\text { Ephedra group }\end{array}$ & $\begin{array}{c}\text { High dose Ephedra } \\
\text { group }\end{array}$ \\
\hline BUN $(\mathrm{mmoL} / \mathrm{L})$ & $6.68 \pm 0.69$ & $25.87 \pm 3.97^{* *}$ & $20.86 \pm 4.67^{*}$ & $15.17 \pm 2.87 * \#$ & $9.46 \pm 1.56 \# \& @$ \\
SCr $(\mu \mathrm{moL} / \mathrm{L})$ & $38.86 \pm 8.23$ & $88.57 \pm 9.96^{* *}$ & $72.52 \pm 8.21^{* * \#}$ & $68.24 \pm 7.63^{* * \#}$ & $43.35 \pm 5.24 \# \# \& @$ \\
$\mathrm{SOD}(\mathrm{U} / \mathrm{mL})$ & $43.45 \pm 9.38$ & $15.5 \pm 4.35^{* *}$ & $19.54 \pm 4.32^{* *}$ & $30.53 \pm 6.95^{* \#}$ & $38.46 \pm 7.64 \# \& \&$ \\
$\mathrm{MDA}(\mathrm{nmoL} / \mathrm{mL})$ & $2.23 \pm 04.3$ & $4.56 \pm 0.89^{*}$ & $4.12 \pm 0.67^{*}$ & $3.73 \pm 0.65 \#$ & $2.88 \pm 0.54 \# \& @$ \\
NO $(\mu \mathrm{moL} / \mathrm{mL})$ & $13.34 \pm 1.32$ & $7.88 \pm 2.25^{*}$ & $9.39 \pm 2.4$ & $15.12 \pm 1.3 \#$ & $22.30 \pm 1.02^{*} \# \# \& \& @$ \\
$\mathrm{eNOS}(\mathrm{ng} / \mathrm{mL})$ & $1.96 \pm 0.47$ & $0.98 \pm 0.24^{* *}$ & $1.47 \pm 0.37 * \#$ & $1.85 \pm 0.48 \#$ & $2.27 \pm 0.53^{*} \# \# \& @$ \\
\hline
\end{tabular}

$*-\mathrm{p}<0.05, * *-\mathrm{p}<0.01$ compared with the control group; \#-p<0.05, \#\#-p<0.01 compared with the model group;

$\&-\mathrm{p}<0.05$ compared with the Ephedra low dose group; @ - $\mathrm{p}<0.05$ compared with the Ephedra middle dose group.

\section{Histopathological changes}

Pathological observation of the kidney tissue under the light microscope showed that the renal tubule lumen of the control group was clear. Epithelial cells were regular in shape and arranged neatly. The glomerular structure was intact. The epithelial cells in the model group showed turbidity with the disorderly arrangement, degeneration and necrosis. The lumen of the renal tubule was narrow with unclear boundaries, and the glomerular atrophy appeared. In the low dose Ephedra group, some renal tubule lumens were irregular, and the epithelial cells were turbid and swollen. The nucleus was located on the luminal side of the epithelial cells, and the glomerular had mild degeneration symptoms. In the middle dose Ephedra group, the epithelial cells were slightly turbid and swollen, and the epithelial nucleus was located in the top of the cells. The glomerular structure was slightly damaged. In the high dose Ephedra group, the epithelial cells were normal in structure, regular in shape, and arranged neatly. The epithelial cells were slightly turbid and the glomerular structure was slightly damaged, which was almost normal (Figure 1).
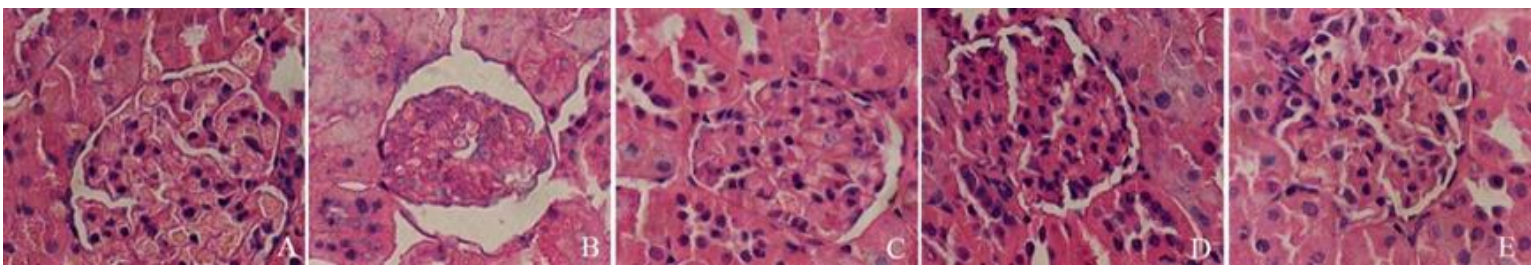

Figure 1.

Pathological changes in kidney tissue (A: control group; B: model group; C: low dose Ephedra group; D: middle dose Ephedra group; E: high dose Ephedra group of Ephedra $(\mathrm{HE} \times 400)$

\section{Renal tissue apoptosis}

No significant apoptotic cells were seen in the control group. The model group shows severe tissue damage

and a large number of apoptotic cells. Tissue damage in the Ephedra groups was slight with scattered apoptotic cells (Table II).

Table II

Renal tissue apoptosis Group Control group $\quad$ Model group $\quad$ Low dose Ephedra group $\quad$ Middle dose Ephedra group High dose Ephedra group \begin{tabular}{ccccc}
\hline AI $1.67 \pm 0.05$ & $35.18 \pm 1.27 * *$ & $18.17 \pm 0.82^{* * \#}$ & $10.25 \pm 0.62^{* \# \# \&}$ & $7.26 \pm 0.27 * \# \&$ \\
\hline$*-\mathrm{p}<0.05, * *-\mathrm{p}<0.01$ compared with the control group; $\#-\mathrm{p}<0.05, \# \#-\mathrm{p}<0.01$ compared with the model group; \\
$\&-\mathrm{p}<0.05$ compared with the low dose group of Ephedra.
\end{tabular}

Bcl-2 and Bax protein expression in kidney tissue Bax protein expression in the model group was significantly up-regulated ( $\mathrm{p}<0.05$ ), and $\mathrm{Bcl}-2$ protein expression was significantly down-regulated $(\mathrm{p}<0.05)$ compared with the control group. Bax protein expression in the Ephedra groups was significantly down-regulated $(\mathrm{p}<0.05)$, while $\mathrm{Bcl}-2$ protein expression was significantly up-regulated $(\mathrm{p}<0.05)$ in a dose-dependent manner compared with the model group (Figure 2). 


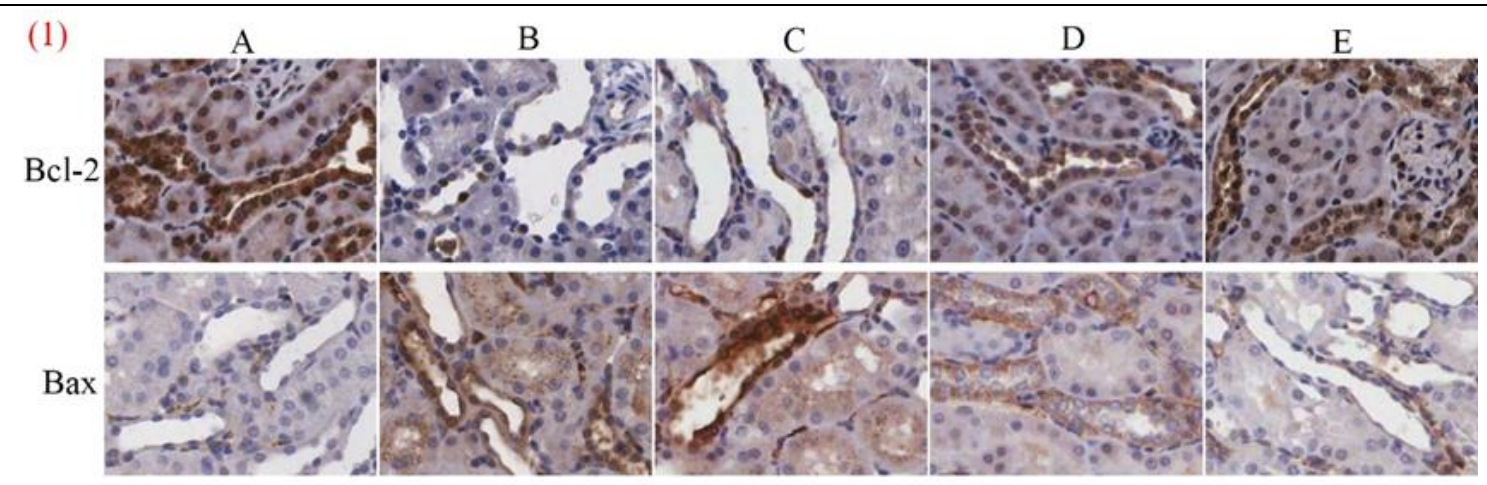

(2)

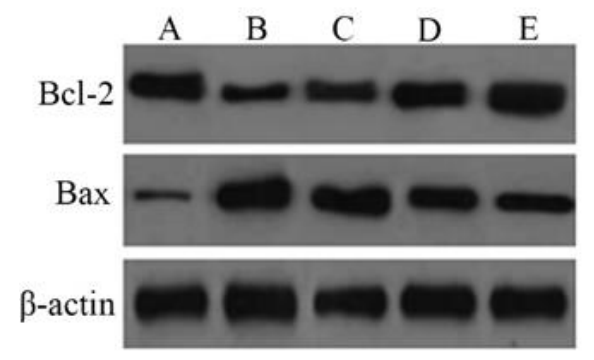

(3)

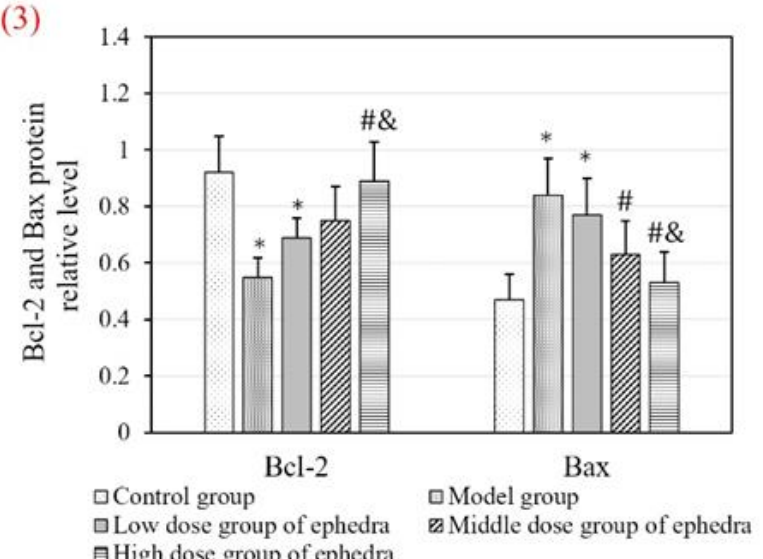

Figure 2.

(1): Various protein expressions tested by immunohistochemistry, $\times 400$; (2): Expressions of Bcl-2 and Bax protein tested by Western blot; (3): Statistics of relative grey values of Bcl-2 and Bax protein

${ }^{*}-\mathrm{p}<0.05$ compared with the control group; ${ }^{\#}-\mathrm{p}<0.05$, compared with the model group; ${ }^{\&}-\mathrm{p}<0.05$ compared with the low dose Ephedra group.

The kidney is a hyperperfused organ and is quite sensitive to ischemia and ischemia-reperfusion. In this study, the renal injury model is replicated by clipping the renal arteries and veins. The results show that renal function was significantly impaired in the model group. Scr and BUN were significantly increased and the renal tubular epithelial cells were severely damaged. After the administration of Ephedra at different doses, Scr and BUN in rats were reduced considerably. The renal tissue damage was alleviated. These results showed that Ephedra can improve kidney function, reduce kidney tissue damage, and has a specific protective effect on renal ischemia-reperfusion in rats. Oxidative stress appears when the organism is exposed to various harmful stimuli that determine the production of reactive oxygen species (ROS) and reactive nitrogen species (RNS) in excess [17]. When oxidative stress appears, the oxidation system and the antioxidant system are imbalanced, resulting in tissue damage [18]. SOD is the main antioxidant enzyme in the body [19]. It is mainly involved in the conversion of superoxide anion free radicals to $\mathrm{H}_{2} \mathrm{O}_{2}$, removing excess reactive oxygen species, protecting chromosomes from damage and preventing gene mutations [20]. The change in SOD activity directly affects the content of intracellular oxygen free radicals, lipid peroxides and their
MDA levels [21]. Therefore, MDA concentration and SOD activity can be used as indexes of the degree of lipid peroxidative damage [22]. The results of this study show that compared with the control group, the MDA levels in the model group were significantly increased, and the SOD activity was reduced considerably. Compared with the model group, the MDA levels in Ephedra groups decreased significantly with the increase of the dose, and the SOD activity increased. It shows that Ephedra can protect against ischemiareperfusion kidney injury by reducing oxygen free radical damage.

Recent studies have shown that nitric oxide (NO) is involved in the pathophysiology of ischemia-reperfusion injury [23]. Nitric oxide synthase (NOS) is the ratelimiting enzyme produced by NO [24]. Under normal circumstances, eNOS produced by endothelial cells is used to maintain a certain amount of NO production in the body. It plays an essential role in regulating vascular tone and blood pressure, relaxing bronchial smooth muscle, and inhibiting platelet aggregation and adhesion [25, 26]. The results of this study showed that compared with the control group, the renal function of the rats in the model group was significantly impaired, and the level of NO was reduced considerably. Compared with the model group, the level of NO 
and eNOS in the Ephedra groups increase gradually with the increase of the dose. Also, the levels of $\mathrm{NO}$ and eNOS in the high dose Ephedra group was significantly higher than that in the control group. It shows that NO plays a decisive regulatory role in the kidney and is beneficial to improve the impaired renal function.

Studies have found that when the ischemia-reperfusion injury occurs, renal tubular epithelial cells are mostly apoptotic cells [27]. Some of the genes that regulate apoptosis are Bcl-2, Bax, p53 and fas [28]. Bcl-2 is an apoptosis-inhibiting gene, and $\mathrm{Bax}$ is a pro-apoptotic gene, which together forms a heterodimer [29]. The $\mathrm{Bcl}-2 / \mathrm{Bax}$ ratio reflects the comparison of pro-apoptotic and anti-apoptotic power and is a key factor in the regulation of apoptosis. Both of them act on the endogenous mitochondrial apoptotic pathway [30, 31]. The results of this study showed that compared with the control group, the apoptosis rate in the model group was significantly increased. Bcl-2 protein was decreased, and Bax protein was increased. After Ephedra administration, the apoptosis rate begins to decrease. Bcl-2 begins to be up-regulated and Bax begins to be down-regulated. Also, the effect of the high dose group of Ephedra was the most significant. It is suggested that Ephedra may have a protective effect on the kidney by up-regulating Bcl-2 expression and down-regulating Bax expression.

\section{Conclusions}

In conclusions, after renal injury caused by ischemiareperfusion, ischemia and hypoxia affect the kidney tissues, and a large amount of oxygen-free radicals are generated. These leads to pathological changes in renal tissues and renal function damage with increase in renal tubular apoptosis. Ephedra can reduce kidney damage and improve kidney function through antioxidant effects, reducing free radical generation, and inhibiting apoptosis by regulating the expression of Bcl-2 and Bax genes implicated in apoptosis. Further studies should be done to evaluate the kidney protective effect of Ephedra in acute kidney injuries associated with ischemia-reperfusion injuries.

\section{Acknowledgement}

This work was supported by Natural Science Foundation Project of Heilongjiang Province (JJ2019LH1585).

\section{Conflict of interest}

The authors declare no conflict of interest.

\section{References}

1. Zhang J, Xia J, Zhang Y, Xiao F, Wang J, Gao H, Liu Y, Rong S, Yao Y, Xu G, Li J, HMGB1-TLR4 signaling participates in renal ischemia reperfusion injury and could be attenuated by dexamethasone-mediated inhibition of the ERK/NF- $\mathrm{BB}$ pathway. Am J Transl Res., 2016; 8(10): 4054-4067.

2. Milsom AB, Patel NS, Mazzon E, Tripatara P, Storey A, Mota-Filipe H, Sepodes B, Webb AJ, Cuzzocrea S, Hobbs AJ, Thiemermann C, Ahluwalia A, Role for endothelial nitric oxide synthase in nitrite-induced protection against renal ischemia-reperfusion injury in mice. Nitric Oxide, 2010; 22(2): 141-148.

3. Abdelkader A, Ho J, Ow CP, Eppel GA, Rajapakse NW, Schlaich MP, Evans RG, Renal oxygenation in acute renal ischemia-reperfusion injury. Am J Physiol Renal Physiol., 2014; 306(9): F1026-F1038.

4. Abdelrahman AM, Al Suleimani Y, Shalaby A, Manoj $\mathrm{P}$, Al-Saadi H, Ali BH, Effect of levosimendan, a calcium sensitizer, on cisplatin-induced nephrotoxicity in rats. Toxicol Rep., 2019; 6: 232-238.

5. Mamoulakis C, Tsarouhas K, Fragkiadoulaki I, Heretis I, Wilks MF, Spandidos DA, Tsitsimpikou C, Tsatsakis A, Contrast-induced nephropathy: Basic concepts, pathophysiological implications and prevention strategies. Pharmacol Ther., 2017; 180: 99-112.

6. Kotowski M, Bogacz A, Bartkowiak-Wieczorek J, Sienko J, Tejchman K, Dziewanowski K, Ostrowski M, Czerny B, Grześkowiak E, Machaliński B, Effect of Interleukin-6 polymorphism on function of the renal allograft funtion and efficacy of immunosuppressive therapy. Farmacia, 2018; 66(5): 791-797.

7. Tsarouhas K, Tsitsimpikou C, Papantoni X, Lazaridou D, Koutouzis M, Mazzaris S, Rezaee R, Mamoulakis C, Georgoulias P, Nepka C, Rentoukas E, Kyriakides Z, Tsatsakis A, Spandidos DA, Kouretas D, Oxidative stress and kidney injury in trans-radial catheterization. Biomed Rep., 2018; 8(5): 417-425.

8. Basile DP, Leonard EC, Beal AG, Schleuter D, Friedrich J, Persistent oxidative stress following renal ischemiareperfusion injury increases ANG II hemodynamic and fibrotic activity. Am J Physiol Renal Physiol., 2012; 302(11): F1494-F1502.

9. Ozyurt H, Irmak MK, Akyol O, Söğüt S, Caffeic acid phenethyl ester changes the indices of oxidative stress in serum of rats with renal ischaemia-reperfusion injury. Cell Biochem Funct., 2001; 19(4): 259-263.

10. Tsamouri MM, Rapti M, Kouka P, Nepka C, Tsarouhas K, Soumelidis A, Koukoulis G, Tsatsakis A, Kouretas D, Tsitsimpikou C, Histopathological evaluation and redox assessment in blood and kidney tissues in a rabbit contrast-induced nephrotoxicity model. Food Chem Toxicol., 2017; 108(Pt A): 186-193.

11. Kuang H, Xia Y, Yang B, Wang Q, Wang Y, Screening and comparison of the immunosuppressive activities of polysaccharides from the stems of Ephedra sinica Stapf. Carbohyd Polym., 2011; 83: 787-795.

12. Xia Y, Kuang H, Yang B, Wang Q, Liang J, Sun Y, Wang Y, Optimum extraction of acidic polysaccharides from the stems of Ephedra sinica Stapf by BoxBehnken statistical design and its anti-complement activity. Carbohydrate Polymers, 2011; 84: 282-291.

13. Ray SD, Patel N, Shah N, Nagori A, Naqvi A, Stohs SJ, Pre-exposure to a novel nutritional mixture containing a series of phytochemicals prevents acetaminopheninduced programmed and unprogrammed cell deaths by enhancing BCL-XL expression and minimizing oxidative stress in the liver. Mol Cell Biochem., 2006; 293(1-2): 119-136. 
14. Zhang LR, Zou GL, Yang TM, Studies on extraction of water-soluble polysaccharides and the function of cleaning oxygen free-radical function of Ephedra. Amino Acids and Biotic Resources, 2000; 22(3): 24-26.

15. Nam NH, Lee CW, Hong DH, Kim HM, Bae KH, Ahn BZ, Antiinvasive, antiangiogenic and antitumour activity of Ephedra sinica extract. Phytother Res., 2003; 17(1): 70-76.

16. Stancu E, Tăerel AE, Soroceanu V, Rais C, Ghica M, Ethical aspects of food supplements in EU and Romania. Farmacia, 2019; 67(4): 736-742.

17. Khader A, Yang WL, Kuncewitch M, Jacob A, Prince JM, Asirvatham JR, Nicastro J, Coppa GF, Wang P, Sirtuin 1 activation stimulates mitochondrial biogenesis and attenuates renal injury after ischemia-reperfusion. Transplantation, 2014; 98(2): 148-156.

18. Pricop C, Puia D, Dragomir Ş, Peride I, Niculae A, Jinga V, Comparative assessment of the benefits of potassium and magnesium tribasic citrate versus tamsulosin in nephrolithiasic patients. Farmacia, 2018; 66(2): 347-353.

19. Potter-Baker KA, Nguyen JK, Kovach KM, Gitomer MM, Srail TW, Stewart WG, Skousen JL, Capadona JR, Development of Superoxide Dismutase Mimetic Surfaces to Reduce Accumulation of Reactive Oxygen Species for Neural Interfacing Applications. J Mater Chem B., 2014; 2(16): 2248-2258.

20. Zhu LJ, Chen YP, Chen BJ, Mei XH, Changes in reactive oxygen species, superoxide dismutase, and hypoxia-inducible factor- $1 \alpha$ levels in missed abortion. Int J Clin Exp Med., 2014; 7(8): 2179-2184.

21. Sun Y, Liu J, Wan L, Wang F, Qi Y, Xinfeng Capsule increases peripheral blood BTLA expression of $\mathrm{CD} 19(+)$ and $\mathrm{CD} 24(+) \mathrm{B}$ cells and relieves oxidative stress damage to improve cardiac function of patients with rheumatoid arthritis. Xi Bao Yu Fen Zi Mian Yi Xue Za Zhi, 2015; 31(1): 93-96, 99.

22. Li X, Zhao L, Yue L, Liu H, Yang X, Wang X, Lin Y, $\mathrm{Qu} \mathrm{Y}$, Evidence for the protective effects of curcumin against oxyhemoglobin-induced injury in rat cortical neurons. Brain Res Bull., 2016; 120: 34-40.

23. Shinbo T, Kokubo K, Sato Y, Hagiri S, Hataishi R, Hirose M, Kobayashi H, Breathing nitric oxide plus hydrogen gas reduces ischemia-reperfusion injury and nitrotyrosine production in murine heart. Am J Physiol Heart Circ Physiol., 2013; 305(4): H542-H550.

24. Qiao S, Olson JM, Paterson M, Yan Y, Zaja I, Liu Y, Riess ML, Kersten JR, Liang M, Warltier DC, Bosnjak ZJ, Ge ZD, MicroRNA-21 Mediates Isoflurane-induced Cardioprotection against Ischemia-Reperfusion Injury via Akt/Nitric Oxide Synthase/Mitochondrial Permeability Transition Pore Pathway. Anesthesiology, 2015; 123(4): 786-798.

25. Wang DJ, Tian H, Zhuang BX, Wu HJ, Effects of intraperitoneal hydrogen injection on nitric oxide synthase mRNA and malondialdehyde following limb ischemia-reperfusion in rabbits. Acta Orthop Traumatol Turc., 2015; 49(5): 558-564.

26. He K, Chen X, Han C, Xu L, Zhang J, Zhang M, Xia Q, Lipopolysaccharide-induced cross-tolerance against renal ischemia-reperfusion injury is mediated by hypoxia-inducible factor- $2 \alpha$-regulated nitric oxide production. Kidney Int., 2014; 85(2): 276-288.

27. Lin M, Li L, Li L, Pokhrel G, Qi G, Rong R, Zhu T, The protective effect of baicalin against renal ischemiareperfusion injury through inhibition of inflammation and apoptosis. BMC Complement Altern Med., 2014; 14: 19.

28. Junnarkar SP, Tapuria N, Mani A, Dijk S, Fuller B, Seifalian AM, Davidson BR, Attenuation of warm ischemia-reperfusion injury in the liver by bucillamine through decreased neutrophil activation and $\mathrm{Bax} / \mathrm{Bcl}-2$ modulation. J Gastroenterol Hepatol., 2010; 25(12): 1891-1899.

29. Xu YY, Liu LL, Liu CC, Cai R, Tian JY, Liu L, Gao $\mathrm{ZP}$, Dynamic expressions of Bcl-2, Bax and p53 in cortex of cerebral ischemia-reperfusion rats. J Jilin Univ Med Ed., 2012; 38: 697-700.

30. Deng YJ, Tan N, Zeng HK, Fu YH, Dong XL, Effects of BNP preconditioning on myocardial cell apoptosis and expressions of bcl-2 and Bax during myocardial ischemia-reperfusion injury in rats. Zhonghua Yi Xue Za Zhi, 2010; 90(48): 3431-3434.

31. Wei-Feng C, Lu W, Rui W, Influence of Aiweixin Liquid on cardiocyte apoptosis of myocardial ischemiareperfusion injury in rats. China J Tradit Chin Med Pharm., 2009; 1521-1523. 